ВІСНИК

ОДЕСЬКОГО НАЦІОНАЛЬНОГО

МОРСЬКОГО УНІВЕРСИТЕТУ

№ 3 (60), 2019
HERALD

OF THE ODESSA NATIONAL

MARITIME UNIVERSITY

№ $3(60), 2019$

UDC 159.923.2

DOI 10.33082/2226-1893-2019-3-156-170

\title{
ECONOMIC ASPECTS OF INTERACTION OF INDIVIDUAL AND SOCIETY IN INFORMATIVE SOCIETY
}

\author{
N.V. Vityuk \\ Ph.D., associate professor \\ Department of «Operation of ship electrical equipment and automation equipment» \\ B.N. Mashin \\ Senior Lecturer, \\ Department of «Operation of ship electrical equipment and automation equipment» \\ Odessa National Maritime University, Odessa, Ukraine
}

Abstract. The economic aspects of relations between an individual and society as the core of development of information society consisting of two new classes - netocrats and consumers are analyzed. The dual attitude of netocrats to scientists is noted. Different approaches to the problem of "planned obsolescence» of household objects are considered. It is emphasized that consumption stimulated by the aggressive impact of information technologies on people depresses their lives, thus destroying the environment. It is concluded that active online advertising attracts individuals to the rows of the consumer. The control over personal data of the computer can turn into a system of estimates of an individual's loyalty.

Keywords: noosphere, information society, information flows, netocrats, consumerism, planned obsolescence, social networks, quality of life, control over personal data, social trustworthiness.

УДК 159.923.2

DOI 10.33082/2226-1893-2019-3-156-170

\section{ЕКОНОМІЧНІ АСПЕКТИ ВЗАЄМОДІЯ ІНДИВІДА І СОЦІУМУ В ІНФОРМАЦЙНОМУ СУСПІЛЬСТВІ}

\author{
М.В. Вітюк \\ к.ф-м.н., доцент, \\ доцент кафедри «Експлуатація суднового електрообладнання \\ та засобів автоматики» \\ B.М. Машін \\ старший викладач кафедри «Експлуатація суднового електрообладнання \\ та засобів автоматики» \\ Одеський національний морський університет, Одеса, Украйна
}

Анотація. Аналізуються економічні аспекти взаємозв'язку індивідуума та соиіуму як стрижня розвитку інформаційного суспільства, що складається з двох нових класів - нетократів та споживачів (консьюмерата).

() Витюк М.В., Машін В.М., 2019 
ВІСНИК

ОДЕСЬКОГО НАЦІОНАЛЬНОГО

МОРСЬКОГО УНІВЕРСИТЕТУ

№ 3 (60), 2019
HERALD

OF THE ODESSA NATIONAL

MARITIME UNIVERSITY № $3(60), 2019$

Відзначається подвійне ставлення нетократії до вчених. Розглядаються різні підходи до проблем «запланованого застарівання» предметів побуту. Підкреслюється, ще споживання, стимульоване агресивним впливом інформаційних технологій на людину, пригнічує його життя, руйнуючи тим самим навколишне середовище. Робиться висновок, що активна мережева реклама затягує індивіда до лав консьюмерата. Контроль над персональними даними консьюмерата може перетворитися 8 систему оцінок лояльності індивіда.

Ключові слова: ноосфера, інформачійне суспільство, інформаиійні потоки, нетократія, консьюмеризм, заплановане застарівання, соиіальні мережі, якість життя, контроль над персональними даними, соиіальна благонадійність.

\section{УДК 159.923.2}

DOI 10.33082/2226-1893-2019-3-156-170

\section{ЭКОНОМИЧЕСКИЕ АСПЕКТЫ ВЗАИМОДЕЙСТВИЯ ИНДИВИДУМА И СОЦИУМА В ИНФОРМАЦИОННОМ ОБЩЕСТВЕ}

\section{Н.В. Витюк}

к. ф-м. наук, доцент, доцент кафедры «Эксплуатация судового электрооборудования и средств автоматики»

В.Н. Машин

старший преподаватель

кафедры «Эксплуатация судового электрооборудования и средств автоматики»

Одесский нацииональный морской университет, Одесса, Украина

Аннотация. Анализируются экономические аспекты взаимоотношений индивидума и социума как стрежня развития информаџионного общества, состоящего из двух новых классов - нетократов и потребителей (консьюмерата). Отмечается двойственное отношение нетократии к ученым. Рассматриваются разные подходы к проблеме «запланированного устаревания» предметов быта. Подчеркивается, что потребление, стимулируемое агрессивным воздействием информационных технологий на человека, угнетает его жизнь, разрушая тем самым окружаюшую среду. Делается вывод, что активная сетевая реклама затягивает индивида в ряды консьюмерата. Контроль над персональными данными консьюмерата может превратиться в систему оценок лояльности индивида.

Ключевые слова: ноосфера, информационное общество, информационные потоки, нетократия, консьюмеризм, запланированное устаревание, социальные сети, качество жизни, контроль над персональными данными, сочиальная благонадежность. 
Preamble. The revolutionary impact of information technology on all spheres of the historical process at the turn of the XX-XXI centuries has led to a new type of society - the information society, which is based not on the production of goods but on the production, storage and sale of information, especially in the field of services.

Mass communication media provide information to the individual, but do not care about its understanding, possibilities of reflection, and this attracts the individual into the ranks of consumers.

The increasing importance of information cause need in considering the «society-information-individual» triad, particular attention be paid to the individual's response to the information flows that affect the individual

Mass media not only provide information, but also confuse its understanding by the individual and involve the individual into the ranks of consumers.

Until a certain turning point is reached, an individual's gaining knowledge in the form of advertising about services and trade stimulates consumption and production growth, which favours economic development. However, having reached the limit of possibilities caused by limited natural resources, the process of increasing consumption takes destructive forms.

Literature analysis. Academician V.I.Vernadsky wrote in March, 1943 about the approaching of noosphere - the new state of human life, when the mind of man becomes geological planetary force. A biosphere, processed by scientific thought Homo Sapiens, goes into a new quality - in a noosphere.

Among the necessary conditions for the creation of the noosphere, V.I. Vernadsky singled out a sharp strengthening of ties between all countries, the creation of conditions favorable for free scientific thought and scientific research [1].

Well-known scientist, futurist-writer I.A. Efremov came to a similar conclusion about the significance of scientific research for the evolutionary process. I.A. Efremov, developing his idea of the similarity of the paths of evolution on different foci of mind in the Universe, proved that evolution has a direction: either a passive adaptation to narrow conditions, or a transformation of the environment. The first path leads to extinction, the second path leads to perfection [2], but requires the accumulation of knowledge about the surrounding world, i.e. information. The history of mankind can be represented as the history of the development of means of accumulation and transmission of information [3].

The purpose of this study is to consider two processes - to survive and to think, which are closely interconnected and represent three «adjacent corners» in the triad «society - information - individual». The interaction of people through the exchange of information is objective and universal. A change in the volume of information flows and its quality leads to significant changes in the system of both social and economic relations and vice versa. 
Basic research material. The current stage of civilizational development is characterized by the presence of global information networks that simultaneously influence a society and an individual.

Over the past five years, mankind has generated more information than in its entire previous history. The investigations of International Data Corporation (an international company engaged in the study of the world market of information technologies and telecommunications) showed [4] that the share of useful information makes up only $35 \%$ of the total volume, and the majority of the remaining $65 \%$ belongs to the field of entertainment - computer games, etc.

YouTube executive director Ryan Wyatt reported that in 2018, the inhabitants of the planet Earth spent more than 50 billion hours (ie 6,5 million years) on watching video game clips [5]. It follows that that information technologies only in 2018 «delayed» the civilizational development of mankind by several million years.

All this indicates that our civilization is acquiring a new quality - the initial stage of the information society [6;7], characterized by the transition from an industry based on the development of technology to a computerized industry based on the transfer of information. The quality of life, the forms of work and rest, the prospects for the social mobility of an individual and the economic development of society are increasingly dependent on information and its operation. Most workers are engaged in the production, storage, processing and sale of information.

The Internet has become the main phenomenon of the information society. Every minute in the world almost 188 million emails are sent, Google processes 3,8 million search requests, 4,5 million videos are viewed on YouTube, 0,39 million applications are downloaded on Google Play and Appstore, 0,4 million on Instagram Views, approximately 1 million dollars are spent on online purchases [8]. A new type of communication has emerged, in which people who directly communicate can be at any point on the surface of the Earth.

The emergence of an electronic form of communication between an individual and a society allowed A. Bard and J. Söderqvist [9] to assert that the Internet will lead to a fundamentally new social system - netocracy (netocracy $=$ «network» + «aristocracy»), consisting of two new classes netocrats and consumerats. The proletariat gives way to consumerats - to the lower class, which is only able to consume information. Power from the owners of material capital goes to netocrats - owners of social information networks that manage information flows and manipulate public consciousness (make it more vulnerable in the sense of self-control and reduce the sense of reality), thereby ensuring their power over the rest of society. 
M. Castells [7], describing the contours of the network society, makes a distinction between capitalist and informational methods of production, when the action of knowledge on knowledge itself becomes the main source of productivity, which leads to the emergence of a new form of social development based on the wide use of non-material assets (first of all, works of science, literature and art; programs for electronic computers; inventions [10]).

This causes the need for knowledge workers (information workers) who are able to analyze, define strategies, communicate effectively, find new opportunities. They form the core of capitalist entrepreneurship. Information workers are people who can retrain as necessary, which makes them highly adapted to survive in the rapidly changing and eerily «flexible» world of informational capitalism [11].

A. Bard and J. Söderqvist [9] suggest that a new phenomenon will appear in the information society, which the authors called Attentionalism (from the word - attention). Information workers are obliged to draw the attention of the network community to the blogs of the netocrats, to force the consumers to «subscribe», leave comments, etc. in other words, to participate actively in the process of manipulation of the public consciousness by the netocrates.

In the information society, attitudes towards scientists are ambiguous.

On the one hand, scientists are needed to ensure scientific and technological progress and maintaining Human well-being (in terms of social, economic, psychological, spiritual or medical status), as well as for the reproduction of information workers. Such a fragment of the scientific community we call the zonder-class (this term in the international classification of sports ballroom dancing corresponds to the highest degree of skill).

On the other hand, a scientist as a carrier of critical thoughts, can reduce the controllability of society. As a result, a scientist is «useful» to society only in a truncated version - like a machine that produces something that benefits.

Unlike physics, chemistry, biology, which bring material benefits, the suppression of the humanitarian sciences does not cause quickly appreciable damage, which makes it possible to reduce the attention of the «customers» to the «unnecessary» sciences. Such an asymmetrical «dismemberment» of scientific progress leads to the degradation of science, which ultimately manifests itself in a decline in the professionalism of scientific workers.

Having deprived a person of feelings, moral dignity, society receives an individual who can easily be bought or intimidated. Such a cynic scientist, endowed with intelligence and necessary knowledge, can become dangerous for mankind, just as science in general is as dangerous as it is, devoid of moral principles, life-saving reference points, which do not allow scientific discovery to become an instrument of crime. 
Sherry Turkle, a professor at the Massachusetts Institute of Technology, writes: «As a society, we make a mistake not when we introduce high-tech innovations, but when we do not think about which aspects of our life will suffer from this damage» [12].

A society, depriving a person of moral dignity, gets an individual who can easily be bought or intimidated. Such a cynic scientist, having intelligence and the necessary knowledge, can become dangerous for humanity. A science devoid of moral principles and guidelines which do not allow scientific discovery becomes an instrument of crime is danger too.

The Internet increases and accelerates the ability to access the necessary information, which allows to draw conclusions about the negative consequences for society of the introduction of innovative technologies into practice. Bill Gates compared the Internet with an «electronic nervous system that has the ability to instantly respond to any changes in the world and analyze the situation, helping people make quick and correct decisions» [13].

The positiveness of the information explosion is that it provides society a lot of various facts, studying which scientists can come to new thoughts and discoveries. The availability of comprehensive information about the phenomenon under study reduces the possibility of erroneous conclusions. And the idea of Rene Descartes that «all sciences are interconnected so much that it is much easier to study them all at once than by separating one from the others» [14] acquires a new heuristic sence for the scientific zonder-class community.

A person in order to realize his social behavior in society needs a constant flow of information. Constant information communication with the outside world, in which individual acts as an active social subject, is one of the most important conditions for normal life activity [15].

The neuroscientist at Illinois Northwestern University, Moran Surf, said that the level of a individual's happiness largely depends on his or her circle of communication and their closest circle [16]. The most important decisions are made under the influence of the environment and set up the individual in a positive way. The process of making an independent decision for most people is simply overwhelming - the resource of mental energy is limited, so many people simply cannot physically choose between «A» and $\langle\mathrm{B} »$ all the time, they really want to shift this function to someone else. To do this, you need to choose a company from people who think in a similar way, and social networks help the individual in this.

The theory of six handshakes is known [17], according to which any two people on Earth are separated by no more than five levels of common friends (and, accordingly, six levels of connections). The mathematical formulation of the theory is as follows: the diameter of the acquaintance graph does not exceed 6. Researchers at the University of Milan found out that in the Internet, the hypothesis of six handshakes was reduced - two people in the world can be familiar with networks through 4,47 handshakes [18]. In addition, 
ВІСНИК

ОДЕСЬКОГО НАЦІОНАЛЬНОГО

МОРСЬКОГО УНІВЕРСИТЕТУ

№ 3 (60), 2019
HERALD

OF THE ODESSA NATIONAL

MARITIME UNIVERSITY № $3(60), 2019$

it became known that about half of Facebook users have more than 100 «friends».

And here appears the contradiction between a decrease in the diameter of an individual's acquaintance graph and a letdown in the quality of his life in society.

In the developed countries of the world, the so-called loneliness epidemic is spreading at a high rate [19]. Over the past 50 years, only in the USA the number of lonely people (not having a romantic relationship) has doubled [20]. The study of the behavior of Americans showed that the more a person has friends in social networks with whom he virtually communicates, the more unhappy he feels in real life outside of online [21].

The reason for this is that any social network gives too beautiful picture of the lives of others. The Internet distracts the user's attention from reality, creates a sense of a large circle of «friends» and acquaintances, makes the user in the status of Homo Interneticus (Man of the Internet) [22] constantly wait for some news, causing fear to miss something from virtual life, in other words, to lose the ability to consume something important. Ultimately, social networks are increasingly drawing Homo Interneticus into the ranks of consumers.

An example of the connection of active network advertising with the consumer behavior of an individual is the phenomenon of a Barbie doll. In Google at the end of May 2019, there were 7,5 million inquiries on the topic «advertisements for Barbie» and 2,9 million inquiries on the topic «psychology of Barbie». The attitudes and behaviors of Barbie learned in childhood are then reproduced on an unconscious level, automatically [23]. This suggests that Homo Interneticus is becoming an integral part of the media space spread externally for consumers [24].

In stimulating consumerism, the special role belongs to the principle of «planned obsolescence» of consumer goods. This principle originated in the 1920 s, when representatives of the world's leading manufacturers of electric incandescent lamps, agreed to artificially reduce the life of their lamps to 1000 hours, while the technology allowed them to produce lamps with a service life of about 2500 working hours. The «Phoebus» cartel was created, controlling the lifespan of competitors' products: if someone's lamps worked too long, the «sinner» manufacturer paid fines to the cartel members. The cunning plan worked: since then, light bulbs began to burn out faster all over the world, and their sales volumes could grow to unprecedented heights [25].

In modern society, planned obsolescence reigns ubiquitous in all areas of production. It should be noted that this principle has some positive qualities - technological innovations are stimulated, new jobs are created - that is, industry is developing.

However, the resource potential of the planet Earth is limited, therefore, it is necessary to consciously limit consumption by society - the rejection of unnecessary excesses, otherwise humanity is doomed to death. 
Consumption based on the natural needs of the individual - supports life and develops it, but venturesome consumerism, stimulated by an aggressive impact on the indivi-dual information technologies subordinates and depresses life, thereby destroying the environment.

The British scientist Tim Berners-Lee, one of the inventors of the Internet and the head of the World Wide Web Consortium (W3C), called the three main threats to the development of the Web, and therefore to the core of the information society. Among those, the «father of the Internet» ranked the loss of control over personal data, the spread of misinformation and the opacity of political advertising [26].

China was the first to take the path that the «father of the Internet» warned against. China has developed a «Social Loyalty Creation Program (2014-2020)», according to which the activities of every citizen will be monitored and evaluated in real time [27].

The system of «social trust» is already operating in pilot mode in about thirty cities in China. Initially, each individual is given a starting trust rating of 1000 points. Further, the rating either grows or falls, depending on the behavior of the individual. Owners of high ratings enjoy various social and economic benefits. And on the owners of low ratings will fall the full force of administrative sanctions and restrictions.

Additional points are awarded for the absence of violations of the law, observance of traffic rules, social and volunteer activity, respectful attitude towards fellow citizens, respect for elders, responsible to parental responsibilities, for «correct» purchases from the point of view of the authorities. Academic progress, timely payment of taxes, credit and utility payments are encouraged. Those who often purchase alcohol or video games will not receive such points. Internet circles, «likes» and preferences on social networks - are assessed for both politeness and political loyalty. The behavior and ranking of online friends will affect individual points. Voluntary assistance of citizens is welcome - an individual who has informed the authorities about the bad deeds of his neighbour will earn a few points.

The points for any crimes and misdemeanours, violation of payment discipline are subtracted. Those who litter, rude, abuse alcohol, do not pay for public transport, and cheat on exams are punished [28].

The scattered information about the life and activity of a citizen comes from municipal, commercial, law enforcement, judicial bodies to the unified information center in Runchen, which analyzes 160 thousand different parameters from 142 institutions and places the ratings of citizens in the public domain in the Internet.

An individual with a rating below 849 is not worthy of service in state and municipal structures. Individuals who did not score a rating of 599 become outcasts. They are restricted from traveling abroad and from staying in luxury hotels. 
They are not hired for any work, they are not given loans, they are not allowed to sell tickets for high-speed trains and airplanes, and they are not allowed to rent a car or bicycle without collateral. Communicating with such an outcast, the individual reduces his personal rating [28].

Time will show whether the social credit system will turn into a digital dictatorship of the XXI century, with the Big Brother (the character of George Orwell's novel «1984»), who is watching you tirelessly. It is also unclear whether there will be any control or limitation for Big Brother himself.

Sociologists have paid attention to the fact that the new system does not clearly state what is possible and what is not. This can lead to administrative arbitrariness in which practically innocent people will suffer.

Bloggers claim that the new system is only a more open method of observing citizens. It becomes known what and where you buy. Bosses can track where you are, at what time. Bosses can evaluate your real expenses, your area of interest, track with whom you communicate in a chat, what are you reading.

Bloggers also noted that if you make small «correct» purchases at least once every three to five days, this will lead to a significant increase in the rating. On this basis, a version arises that consumerism can be one of the essential factors of loyalty [27].

Here lies the danger of the transformation of the information society into a civilization described by Stanisław Lem in 1958 in the science fiction novel «Eden» [29].

As follows from the story of the aborigen-scientist to astronauts from Earth, the control of Eden is carried out by using some information, the name of which the electronic calculator-translator could translate as «procrustika» (from «Procrustean bed»- a legendary measure of violent bringing diversity to a single).

It is strictly forbidden to know this information to aborigines on Eden who are not included in the circle of favorites. All the information comes from the ruling circles, which seem to be absent. «Limited» knowledge is clearly focused on each social group. For the natives of Eden, power seems to be taken from nowhere and strictly measured for everyone, so that members of society behave as programmed by invisible rulers. By denying its own existence, the power of Eden ensures its invulnerability due to the depersonization of the population, but the civilization of Eden has reached an impasse, degraded and is moving towards its own destruction.

Conclusions. The social process modeled in the novel «Eden» by St.Lem showed the danger of a significant lagging the moral progress in the relationship between the individual and society in comparison with the rates of economic and scientific-technical development. 
The risks of the civilizational development of society lie in the fact that society takes too much from nature, but almost does not return anything, violating the laws of ecology of Commoner Barry [30].

\section{СПИСОК ЛІТЕРАТУРИ}

1. Вернадский В.И. Начало и вечность жизни. М., 1989. 611-612 c.

2. Карпеи А., Ефремов I. Антрополог и поэт научного nоиска. URL: https://fraza.ua/analytics/244176-ivan_efremov_ antropolog_i poet_nauchnogo_poiska (дата обращения 16.04.2019).

3. Информационные технологии: понятийная и структурная характеристика. URL: https://sites.google.com/sitel infotrmattehnologi/nalastuvanna (дата обращения 16.04.2019).

4. Сколько информачии накопило человечество? URL: https:// www.infox.ru/news/9/science/technology/64630-skolko-informaciinakopilo-celovecestvo? (дата обращения 23.04.2019).

5. За 2018 год на Үои Тиве смотрели 50 млрд. часов игровых видео URL: https://imgame.kz/news/za-2018-god-na-youtubeprosmotreli-50-mlrd-chasov-igrovyh-video/ (дата обращения 25.04.2019).

6. Воронина Т.П. Информационное общество: сущность, черты, проблемы. М., 1995. $111 \mathrm{c}$.

7. Кастельс М. Информационная эпоха: экономика, общество и культура / Пер. с англ. под науч. ред. О.И. Шкаратана. М.: ГУ ВШЭ, 2000. 608 c.

8. Минута в интернете. 10 фактов о том, что делают пользователи по всему миру. URL: https://www.vestifinance.ru/ articles/116279 (дата обращения 03.07.2019).

9. Бард А., Зодерквист Я. Nетократия. Новая правящая элита и жизнь после капитализма / Перевод с шведского языка. СПб.: Стокгольмская школа экономики в Санкт-Петербурге, 2004. $252 \mathrm{c}$.

10. Нематериальные активы. URL: http://msfo-dipifr.ru/ nematerialnye-aktivy-chto-k-nim-otnositsya-v-buxgalterskom-uchete-primery-uchet-po-msfo-ias-38/. (дата обрашения 03.07.2019).

11. Кравчик А. Существует ли сегодня «сетевой капитализм»? URL: http://www.slovo.odessa.ua/news/26949-suschestvuet-li-segodnya-setevoy-kapitalizm.html (дата обращения 16.04.2019).

12. Читать лучше бумажные книги. URL: http://nastroenie. com.ua/articles/109496.html (дата обращения 16.04.2019). 
ВІСНИК

ОДЕСЬКОГО НАЦІОНАЛЬНОГО

МОРСЬКОГО УНІВЕРСИТЕТУ

№ 3 (60), 2019
HERALD

OF THE ODESSA NATIONAL

MARITIME UNIVERSITY

13. Гейтс Билл. «Компьютерные технологии - дорога в двадияать первый век» HARD'n 'SOFT. 1998. № 10. C. 45-67.

14. Декарт Рене: Правила для руководства ума. Правило I. URL:https://gtmarket.ru/laboratory/basis/3958. (дата обращения 16.05.2019).

15. Демьянова Е. Г., Колесник А. А. Информационная зависимость как психолого-педагогическая проблема. «Молодой ученый». 2014. № 4., C. 943-945.

16. Ученые раскрыли формулу счастья. URL: https://podrobnosti.ua/2212351-uchenye-raskryli-formulu-schastja-2.html (dama обращения 16.05.2019).

17. Теорию шести рукопожатий подтвердили специалисты Місrosoft. URL: http://www.membrana.ru/particle/12894 (даma обращения 16.05.2019).

18. Теорию шести рукопожатий сократили до пяти. URL: https:// rb.ru/article/teoriyu-shesti-rukopojatiy-sokratili-do-pyatil 6825807. html (дата обращения 16.05.2019).

19. Одиночество вредно для сердия URL: https://med.vesti.ru/ novosti/issledovaniya-i-otkrytiya/odinochestvo-vredno-dlya-serdtsa/ (дата обращения 16.05.2019).

20. Одна у монитора: мешают ли социальные сети нормальной жизни? URL: https://www.cosmo.ru/lifestyle/stil-zhizni/odna-umonitora-meshayut-li-socialnye-seti-normalnoy-zhizni/ (даma обращения 16.05.2019).

21. Поддерживать дружеские отношения в соисетях оказалось не проще, чем в жизни. URL: https://chrdk.ru/news/ podderzhivat_druzheskie_otnosheniya_v_sotssetyah_okazalos_ne_ proshhe chem v zhizni (дата обрамения 16.05.2019).

22. Витюк Н.В., Витюк А.Н., Машин B.H. Om Homo Sapiens через Homo Interneticus $\kappa$ Hoто Sapientissimus (От Человека Разумного через Человека Интернетствующего к Человеку Разумнейшему) Материаль VI международной научно-практической конференции «Информационные контрольные системы и технологии», Одесса, ОНМУ, 2017. С. 85-86.

23. Шишова Т. Психология Барби, «Родительский комитет»/ URL: http://www.rodkom.com.ua/psihologiya-barbi/ (даma oбpaщения 06.06.2019).

24. Старовойт М.В. Особенности потребительского поведения пользователей Интернета. URL: http://www.mediascope.ru/ 1550 (дата обращения 06.06.2019).

25. Adam Hadhazy «Planned Obsolescence» Treacherous Conspiracy of Producers? URL: http://www.bbc.com/future/story/20160612heres-the-truth-about-the-planned-obsolescence-of-tech (date of address 06.06.2019). 
ВІСНИК

ОДЕСЬКОГО НАЦІОНАЛЬНОГО

МОРСЬКОГО УНІВЕРСИТЕТУ

№ 3 (60), 2019
HERALD

OF THE ODESSA NATIONAL

MARITIME UNIVERSITY

26. Изобретатель интернета назвал три вещи, угрожающче будущему сети. URL: https://www.trn.ua/articles/10054 (дата обращения 08.06.2019)

27. Большой брат 2.0. Как Китай строит ичифровую диктатуру. URL: https://carnegie.ru/commentary/71546/ (дата обращчения 06.06.2019).

28. Альбина Э. Стимулирование благонадежности. «Слово», № 12 (1289) 2018.

29. Станислав Лем. Собрание сочинений в 10 m. Том 1. Моя жсизь. Эдем. Расследование. М., 1992.

30. Коммонер Барри. Замькающийся круг. М.: Гидрометеоиздат, 1974. $280 \mathrm{c}$.

\section{REFERECES}

1. Vernadskyy V.Y.(1989) Nachalo y vechnost' zhyzny [The beginning and eternity of life]. Moscow, pp. 611-612 (in Russian).

2. Karpets A., Efremov I. Antropoloh y poet nauchnoho poyska [Anthropologist and poet of scientific research]. Available at https://fraza.ua/analytics/244176-ivan efremov_antropolog_i poet_nauchnogo_poiska (accessed 16 April 2019).

3. Ynformatsyonnie tekhnolohyy: ponyatyynaya y strukturnaya kharakterystyka. [Information technology: conceptual and structural characteristics]. Available at https://sites.google.com/site/ informattehnologi/nalastuvanna (accessed 16 April 2019).

4. Skol'ko ynformatsyy nakopylo chelovechestvo? [How much information has accumulated by mankind?]. Available at https:// www.infox.ru/news/9/science/technology/64630-skolko-informaciinakopilo-celovecestvo (accessed 24 April 2019).

5. Za 2018 hod na You Tube smotrely $50 \mathrm{mlrd}$. chasov yhrovikh video [In 2018, 50 billion hours of game videos were watched on You Tube]. Available at https://imgame.kz/news/za-2018-god-nayoutube-prosmotreli-50-mlrd-chasov-igrovyh-video/ (accessed 25 April 2019).

6. Voronyna T.P. (1995) Ynformatsyonnoe obshchestvo: sushchnost', cherti, problem [Information Society: Essence, Traits, Problems]. Moscow (in Russian)

7. Kastel's M. (2000) Ynformatsyonnaya epokha: ekonomyka, obshchestvo y kul'tura [The Information Age: Economics, Society and Culture]. Moscow: HU VShe. (in Russian).

8. Mynuta v ynternete. 10 faktov o tom, chto delayut pol'zovately po vsemu myru [A minute on the Internet. 10 facts about what users around the world do]. Available at https://www. vestifinance.ru/ articles/116279 (accessed 03 July 2019). 
9. Bard A., Zoderkvyst Ya. (2004) Netokratyya. Novaya pravyashchaya elyta y zhyzn' posle kapytalyzma [Soderquist I. Netocracy. The new ruling elite and life after capitalism]. St. Petersburg: Stok-hol'mskaya shkola эkonomyky $v$ Sankt-Peterburhe. (in Russian)

10. Nemateryal'nie aktyvi [Intangible assets]. Available at http://msfo-dipifr.ru/nematerialnye-aktivy-chto-k-nim-otnositsyav-buxgalterskom-uchete-primery-uchet-po-msfo-ias-38/ (accessed 03 July 2019)

11. Kravchyk A. Sushchestvuet ly sehodnya «setevoy kapytalyzm»? [Does «network capitalism» exist today?]. Available at http://www.slovo.odessa.ua/news/26949-suschestvuet-li-segodnyasetevoy-kapitalizm.html (accessed 16 April 2019)

12. Chytat' luchshe bumazhnie knyhy [Read better paper books] Available at http://nastroenie.com.ua/articles/109496.html (accessed 16 April 2019).

13. Gates Bill (1998) Komp'yuternie tekhnolohyy-doroha v dvadtsat' perviy vek [Computer technology - the road to the twenty-first century]. HARD'n'SOFT, no.10, pp. 45-67.

14. Dekart Rene Pravyla dlya rukovodstva uma. Pravylo I [Rules to guide the mind. Rule I]. Available at https:// gtmarket.ru/laboratory/basis/3958 (accessed 16 May 2019).

15. Demyanova E.G., Kolesnik A.A. (2014) Ynformatsyonnaya zavysymost' kak psykholoho-pedahohycheskaya problema [Information dependence as a psychological and pedagogical problem]. Kherson: Young scientist, no.4, pp. 943-945.

16. Uchenie raskrily formulu schastija [Scientists have discovered the formula for happiness]. Available at https:// podrobnosti. ua/ 2212351-uchenye-raskryli-formulu-schastja-2.html (accessed 16 May 2019).

17. Teoryyu shesty rukopozhatyy podtverdyly spetsyalysti Microsoft [The theory of six handshakes confirmed by Microsoft]. Available at http://www.membrana.ru/particle/12894 (accessed 16 May 2019)

18. Teoryyu shesty rukopozhatyy sokratyly do pyaty [The theory of six handshakes was reduced to five]. Available at https://rb.ru/ article/teoriyu-shesti-rukopojatiy-sokratili-do-pyati/ 6825807. html (accessed 16 May 2019).

19. Odynochestvo vredno dlya serdtsa [Loneliness is bad for the heart]. Available at https://med.vesti.ru/novosti/issledovaniya-iotkrytiya/odinochestvo-vredno-dlya-serdtsa (accessed 16 May 2019). 
ВІСНИК

ОДЕСЬКОГО НАЦІОНАЛЬНОГО

МОРСЬКОГО УНІВЕРСИТЕТУ

№ 3 (60), 2019
HERALD

OF THE ODESSA NATIONAL

MARITIME UNIVERSITY

20. Odna u monytora: meshayut ly sotsyal'nie sety normal'noy zhyzny?[One at the monitor: do social networks interfere with normal life?]. Available at https://www.cosmo.ru/lifestyle/stilzhizni/ odna-u-monitora-meshayut-li-socialnye-seti-normalnoyzhizni/ (accessed 16 May 2019).

21. Podderzhyvat' druzheskye otnoshenyya $v$ sotssetyakh okazalos' ne proshche, chem $v$ zhyzny [Maintaining friendships in social networks was not easier than in life]. Available at https:// chrdk.ru/news/podderzhivat_druzheskie_otnosheniya_v_sotssetyah okazalos ne proshhe chem_v zhizni (accessed 16 May 2019).

22. Vityuk N.V. ., Vityuk A.N., Mashin V.N. Ot Homo Sapiens cherez Homo Interneticus $k$ Homo Sapientissimus (Ot Cheloveka Razumnoho cherez Cheloveka Ynternet stvuyushcheho $k$ Cheloveku Razumneyshemu [From Homo Sapiens through Homo Interneticus to Homo Sapientissimus (From Homo sapiens through Homo sapiens to Homo sapiens)]. Proceedings of the VI mezhdunarodnaya nauchno-praktycheskaya konferentsyya "Ynformatsyonnie kontrol'nie systemi y tekhnolohyy» (Ukraine, Odessa, September 23-25, 2017), Odessa: OHMY, pp. 85-86.

23. Shyshova T. Psykholohyya Barby "Rodytel'skyy komytet» [Barbie Psychology, "Parents Committee»] Available at http://www. rodkom.com.ua/psihologiya-barbi/ (accessed 06 June 2019).

24. Starovoyt M.V. Osobennosty potrebytel'skoho povedenyya pol'zovateley Ynterneta [Features of consumer behavior of Internet users]. Available at http://www.mediascope.ru/1550 (accessed 06 June 2019).

25. Adam Hadhazy, «Planned Obsolescence» Treacherous Conspiracy of Producers? Available at http://www.bbc.com/ future/ story/ 20160612-heres-the-truth-about-the-planned-obsolescence-of-tech (accessed 06 June 2019).

26. Yzobretatel' ynterneta nazval try veshchy, uhrozhayushchye budushchemu sety [Internet inventor names three things that threaten the future of the network]. Available at https://www. trn.ua/articles/10054 (accessed 08 June 2019).

27. Bol'shoy brat 2.0. Kak Kytay stroyt tsyfrovuyu dyktaturu [Big brother 2.0. How China is building a digital dictation tour]. Available at https://carnegie.ru/commentary/71546/ (accessed 08 June 2019).

28. Alibyna. E. (2018) Stymulyrovanye blahonadezhnosty [Promoting Reliability]. Slovo, no 12 (1298) (in Russian). 
ВІСНИК

ОДЕСЬКОГО НАЦІОНАЛЬНОГО

МОРСЬКОГО УНІВЕРСИТЕТУ

№ 3 (60), 2019
HERALD

OF THE ODESSA NATIONAL

MARITIME UNIVERSITY № 3 (60), 2019

29. Stanyslav Lem. (1992) Tom 1. Moya zhyzn'. Edem. Rassledovanye [Volume 1. My life. Eden. Investigation]. Sobranye sochynenyy v 10 tomakh [Collected works in 10 volumes]. Moscow (in Russian)

30. Kommoner Barry. (1974) Zamikayushchyysya kruh [Closing circle]. Moscow: Hydrometeoyzdat (in Russian)

Стаття надійшла до редакиії 01.09.2019 